\title{
Neuropathic Pain in Pancreatic Cancer: An Update of the Last Five Years
}

\author{
Raffaele Pezzilli
}

Citation: Pezzilli, R. Neuropathic Pain in Pancreatic Cancer: An Update of the Last Five Years. Gastroenterol. Insights 2021, 12, 302-309. https:// doi.org/10.3390/gastroent12030027

Academic Editor: Yasushi Sasaki

Received: 31 May 2021

Accepted: 24 June 2021

Published: 25 June 2021

Publisher's Note: MDPI stays neutral with regard to jurisdictional claims in published maps and institutional affiliations.

Copyright: (C) 2021 by the author. Licensee MDPI, Basel, Switzerland. This article is an open access article distributed under the terms and conditions of the Creative Commons Attribution (CC BY) license (https:/ / creativecommons.org/licenses/by/ $4.0 /)$.
Potenza County Medical Association, 85100 Potenza, Italy; raffaele.pezzilli.qajz@bo.omceo.it or raffaele.pezzilli@gmail.com; Tel.: +39-09711564229

\begin{abstract}
Pain is the main symptom of pancreatic cancer (pancreatic ductal adenocarcinoma, PDAC). Pain in pancreatic cancer may be visceral, somatic or neuropathic in origin. Pain is produced by tissue damage, inflammation, ductal obstruction and infiltration. Visceral nociceptive signals caused by damage to the upper abdominal viscera are carried along sympathetic fibers, which travel to the celiac plexus nerves and ganglia, which are found at the T12-L2 vertebral levels, anterolateral to the aorta near the celiac trunk. From here, the signals are transmitted through the splanchnic nerves to the T5-T12 dorsal root ganglia and then on to the higher centers of the central nervous system. Somatic and neuropathic pain may arise from tumor extension into the surrounding peritoneum, retroperitoneum and bones and, in the latter case, into the nerves, such as the lumbosacral plexus. It should also be noted that other types of pain might arise because of therapeutic interventions, such as post-chemoradiation syndromes, which cause mucositis and enteritis. Management with non-steroidal anti-inflammatory agents and narcotics was the mainstay of therapy. In recent years, celiac plexus blocks and neurolysis, as well as intrathecal therapies have been used to control severe pain, at times resulting in a decreased need for drugs, avoiding their unwanted side effects. Pain may impair the patient's quality of life, negatively affecting patient outcome and resulting in increased psychological stress. Even after recognizing the negative effect of cancer pain on patient overall health, studies have shown that cancer pain is still undertreated. This review focuses on neuropathic pain, which is difficult to handle; thus, the most recent literature was reviewed in order to diagnose neuropathic pain and its management.
\end{abstract}

Keywords: pancreatic neoplasms; pain management; visceral pain; nociceptive pain; systematic review

\section{Introduction}

Pain is the main symptom of pancreatic cancer (pancreatic ductal adenocarcinoma, PDAC), affecting $75 \%$ of patients at the time of diagnosis and over $90 \%$ of those in advanced stages [1]. This review focuses on neuropathic pain, which is difficult to handle; thus, the most recent literature was reviewed in order to diagnose neuropathic pain and its management.

\section{Pancreatic Pain Diagnosis and Treatment: What We Know}

Pain in pancreatic cancer may be visceral, somatic or neuropathic in origin. Pain is produced by tissue damage, inflammation, ductal obstruction and infiltration. Visceral nociceptive signals caused by damage to the upper abdominal viscera are carried along sympathetic fibers that travel to the celiac plexus nerves and ganglia, which are found at the T12-L2 vertebral levels [2,3], anterolateral to the aorta near the celiac trunk. From here, the signals are transmitted through the splanchnic nerves to the T5-T12 dorsal root ganglia and then on to the higher centers of the central nervous system. Somatic and neuropathic pain may arise from tumor extension into the surrounding peritoneum, retroperitoneum and bones and, in the latter case, into the nerves, such as the lumbosacral plexus. It should also be noted that other types of pain may arise as a consequence of therapeutic interventions, such as post-chemoradiation syndromes, which cause mucositis and enteritis [4]. 
Clinical examination should focus especially on the presence of two prominent symptoms: allodynia, which is a painful response to a normally innocuous stimulus, and hyperalgesia, which is an increased pain response to a normally painful stimulus [5]. There is no diagnostic gold standard for neuropathic pain, and so diagnosis is based on clinical judgement; the elements of this process are to identify painful symptoms and a clinical history that all match a neuroanatomical pattern [6].

Historically, management with non-steroidal anti-inflammatory agents and narcotics was the mainstay of therapy. In recent years, celiac plexus blocks and neurolysis, splanchnicectomy and intrathecal therapies have been used to control severe pain, at times resulting in a decreased need for drugs, avoiding their unwanted side effects. Pain may impair the patient's quality of life (QoL), negatively affecting patient outcome and resulting in increased psychological stress. Even after recognizing the negative effect of cancer pain on patient overall health, studies have shown that cancer pain is still undertreated [7].

\section{Literature Search}

A search on PubMed was carried out using the MESH terms pancreatic cancer and pain, which were applied to full texts of papers published in the last 5 years in the English language. As reported in Figure 1, a total of 244 papers were found. Of these 244 papers, 50 were excluded because they reported data referring to topics different from those related to the aim of this study. Of the 194 remaining papers, 161 were excluded because they were case reports, review articles or papers containing no original data. Thus, 33 papers were finally selected. Of these 33 papers, 1 referred to the pathophysiology of pain, 5 to experimental data on animals, 8 to the well-being of patients with pancreatic cancer pain and 19 to the therapy of neuropathic pain.

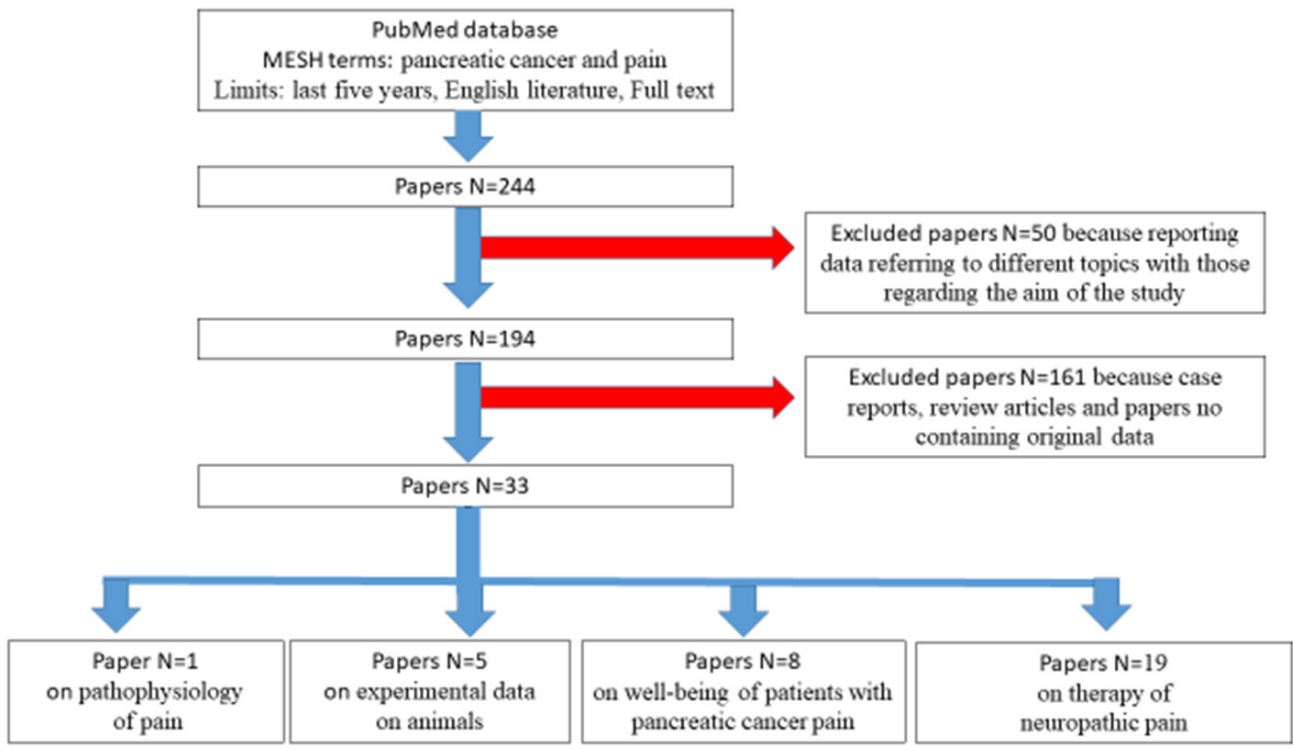

Figure 1. PRISMA flow chart of selected literature.

\section{Experimental Studies of Neuropathic Pain}

From an anatomical point of view, genetically engineered mice have increasingly been used to study neuropathy and neural invasion due to pancreatic cancer. Saricaoglu and coworkers showed that nerve trunks in the mouse pancreas were exclusively located around the intrapancreatic lymphoid structure and vessels, and analyzed the density of the nerve trunks, particularly of the sensory nerves, which was highest in the pancreatic head [8].

From a functional point of view, Han et al. tested the potential influence of the sonic hedgehog $(\mathrm{sHH})$ signaling pathway on pancreatic cancer pain [9]. The authors reported that after orthotopically transplanting tumor cells into nude mice, the sHH signaling pathway increased the expression of substance P (SP) and the calcitonin gene-related peptide (CGRP) in dorsal root ganglia in a concentration- and time-dependent manner. In 
addition, they also reported that $\mathrm{sHH}$ secretion from pancreatic cancer cells could activate the sHH signaling pathway and, in turn, increase the expression of the nerve growth factor (NGF), P75 and tropomyosin receptor kinase A (TrkA) in dorsal root ganglia. Furthermore, the $\mathrm{sHH}$ signaling pathway and the NGF/NGF receptor contributed to pain sensitivity in a nude mouse model. In conclusion, pancreatic cancer pain may originate from the $\mathrm{sHH}$ signaling pathway, and the NGF may mediate the pain mechanism by means of regulating SP and the CGRP.

A team of researchers has postulated that differentially expressed genes (DEGs) associated with perineural invasion (PNI) could identify molecular alterations and potential therapeutic targets for PDAC [10]. In an in vivo model of PNI, they used five pancreatic cancer cell lines (PANC-1, CFPAC-1, CAPAN-2, SW1990 and ASPC-1) divided into two groups: High (PANC-1, CFPAC-1 and CAPAN-2) and low (comprising SW1990 and ASPC-1) PNI. The DEGs in the two groups were identified using the GSE26088 dataset and were regarded as PNI-associated genes. A total of 445 DEGs associated with PNI (fold change $>1.5$ or $<0.66 ; p<0.05$ ) were identified including 176 upregulated and 269 downregulated genes. Of these DEGs, fibroblast growth factor 2 (FGF2) and catenin $\alpha 2$ were associated with PNI, and clinical tissue microarray analysis also demonstrated that FGF2 was associated with PNI and a poor prognosis. The results of this study provided a potential method for identifying PNI-associated genes in order to identify potential therapeutic targets.

Hirth et al. [11] identified CCL21 and CXCL10 as proteins that promote the migration of pancreatic cancer cells toward the sensory neurons. The inhibition of these chemokines or their receptors reduces hypersensitivity in mice with orthotopic tumors; patients with pancreatic cancer having high levels of the chemokine receptors of CXCR3 and CCR7 had an increased frequency of cancer-associated pain.

MicroRNAs play a major role in chronic pain by suppressing the key molecules involved in nociception. Zhu et al. reported that microRNA (miR) 330 is highly expressed in the spinal dorsal horn of nude mice with pancreatic cancer pain [12]. Mimicking pancreatic carcinomainduced spinal dorsal horn miR-330 upregulation by the microinjection of miR-330 mimic into the spinal dorsal horn significantly induced abdominal mechanical allodynia in normal nude mice. They also found that the expression of gamma-aminobutyric acid (GABA) was significantly decreased in the spinal dorsal horn of nude mice with pancreatic cancer pain and was regulated directly by miR-330 both in vitro and in vivo. Furthermore, inhibition of miR330 reduced the expression of GABA and alleviated pancreatic carcinoma-induced abdominal pain hypersensitivity in nude mice with pancreatic carcinoma. These results showed that miR-330 participated in the genesis of pancreatic carcinoma-induced pain hypersensitivity by inhibiting GABA expression in the spinal dorsal horn and might be of potential therapeutic value for pancreatic cancer pain.

These studies showed that nociceptive pain is related to the localization of the pain and that several substances are involved in the origin of nociceptive pain, which should be investigated in humans.

\section{Human Studies}

Fujisawa et al. [13] identified the overexpression of interleukin-13 receptor alpha2 regarding PNI in 236 pancreatic cancer samples and evaluated its expression at the protein levels using immunohistochemistry (IHC) and at the RNA level using in situ hybridization (ISH). The authors observed that more than $75 \%$ samples overexpressed interleukin- 13 receptor alpha 2 by IHC and ISH in grade 2 and 3 tumors while more than $64 \%$ of the stage II and III tumors overexpressed interleukin-13 receptor alpha2. More than 36\% of the peripancreatic neural plexus and more than $70 \%$ of the nerve endings having PNI in the PDAC samples showed higher levels of interleukin-13 receptor alpha2. The interleukin-13 receptor alpha2 positive peripancreatic neural plexus and nerve ending subjects survived for a significantly shorter period of time than interleukin-13 receptor alpha2 positive subjects, suggesting that interleukin-13 receptor alpha2 may have an important role as a biomarker of PNI aggressiveness and may be a therapeutic target for intervention in order to prolong patient survival and alleviate pain due to perineural invasion. 


\section{How to Assess Well-Being in Patients with Neuropathic Pain}

Even if the three main types of pain in pancreatic cancer are well known, studies regarding quality of life have not specifically evaluated neuropathic pain. Many studies, and also systematic reviews with or without a metanalysis, have not evaluated neuropathic pain, only the presence of the pain and its effects on the well-being of patients [14-21]. Thus, we need specific studies on this topic in order to obtain more knowledge regarding the diagnosis and treatment of neuropathic pain and also to guide the development of tailored emotional management programs for cancer survivors that meet the public's needs more effectively. Finally, the QoL scores of patients with pancreatic neuropathic pain could be used for shared decision-making regarding disease management and treatment choice.

\section{Treatment of Neuropathic Pain}

\subsection{Pharmacological Therapy}

It has been reported that duloxetine, a serotonin-noradrenaline reuptake inhibitor, improved the quality of life in a mouse model of PDAC [22]. Duloxetine mainly improves cancer-associated pain by enhancement of the noradrenergic pathway rather than the serotonergic pathway; in addition, duloxetine modulates antitumor effects in pancreatic cancer without involvement of the noradrenergic pathway.

In a phase II, randomized, placebo-controlled trial of patients diagnosed with advanced pancreatic cancer who were scheduled for standard chemotherapy, the patients received $100 \mathrm{mg}$ of minocycline or a placebo given twice a day [23]. Forty-four patients were recruited, but 31 were analyzed; 18 received minocycline and 13 a placebo. There was no observed symptom reduction with minocycline as compared with the placebo; therefore, this drug should not be suggested as pain treatment in patients with advanced pancreatic cancer. On the other hand, methadone, especially in the form of a low-dose add-on to other opioids, is widely advocated in Swedish specialized palliative care as a practical and safe method with rapid onset in complex pain situations at the end of life [24]. It is important to consider regarding the dosage of this class of drugs that in a study comprising 240 patients with cancer (118 in the low-dose morphine and 122 in the weak-opioid group), the percentage of responder patients was significantly higher in the low-dose morphine group as early as at 1 week ( $88.2 \%$ of the low-dose morphine vs. $57.7 \%$, in the weak opioid group) [25].

It should be also underlined that in patients with metastatic pancreatic adenocarcinoma, high opioid use is associated with decreased survival, but the severity of baseline pain and MOP-R expression score in tumor tissue does not correlate with clinical outcomes [26].

The safety and efficacy of intrathecal drug delivery systems (IDDSs) for the treatment of cancer-related pain have been demonstrated in randomized controlled clinical trials, but despite positive evidence for this therapy [27] IDDSs remain underutilized in treating cancer pain. Real-world registry data support the use of intrathecal drug delivery system as a treatment option for cancer-related pain based on 1403 patients prospectively enrolled. Overall device performance and safety along with positive outcomes in pain management and quality of life for the subset of patients available for analysis were demonstrated. Infection requiring surgical intervention (IDDS explant, replacement, pocket revision, irrigation and debridement) was reported in $3.2 \%$ of patients. In addition, after open pancreatic tumor resection, continuous wound infusion is safe and associated with decreased opioid requirements and improved functional outcomes without a negative impact on pain scores, supporting its potential for preferred use over patient-controlled analgesia or epidural analgesia alone [28].

It has also been reported [29] that following pancreaticoduodenectomy, preoperative opioid users had worse pain scores, received more opioids at discharge, refilled prescriptions more frequently and were more likely to have a prolonged length of hospital stay. As most opioid utilization research has been focused on low-complexity surgery, more information is needed in order to optimize opioid use in complex oncologic surgery, such as pancreatic resection. 
It has also been reported that tapentadol may be useful in the treatment of neuropathic pain; however, the results of a systematic review conclude that this drug requires more robust studies including randomized controlled trials to evaluate the efficacy and safety [30]. There are also no studies of tapentadol in human pancreatic cancer.

\subsection{Radiological Therapy}

The short-term curative effect of computed tomography-guided radioactive 125I (125-Iodine) seed implantation (CTRISI) therapy for advanced pancreatic cancer patient pain has been explored [31]. In 37 patients with advanced pancreatic cancer pain, cancer pain levels and daily hydroxycodone dose were compared before and after CTRISI. After one week, one month and two months of implantation, the numerical rating scale scores were significantly lower than the preoperative scores, and the daily dose of hydroxycodone at one week and one month after surgery were significantly lower than the presurgical dose. After 2 months of implantation, the beneficial effect was lost, and the daily hydroxycodone dose was not different from the preoperative dose $(p=0.198)$. Thus, this procedure should be used only for short-term therapy.

\subsection{Celiac Plexus Block}

The studies comparing celiac block neurolysis and mixed control groups are reported in Table 1. No randomized studies showed any efficacy of celiac block neurolysis.

Table 1. Studies regarding celiac plexus neurolysis.

\begin{tabular}{|c|c|c|c|c|c|c|c|}
\hline $\begin{array}{c}\text { Study } \\
\text { Reference }\end{array}$ & $\begin{array}{l}\text { Type of } \\
\text { Study }\end{array}$ & Type of Intervention & $\begin{array}{l}\text { Interventional } \\
\text { Group }\end{array}$ & $\begin{array}{l}\text { Control } \\
\text { Group }\end{array}$ & $\begin{array}{l}\text { Outcomes } \\
\text { Measures }\end{array}$ & $\begin{array}{c}\text { Time } \\
\text { Evaluation }\end{array}$ & Differences \\
\hline [32] & $\begin{array}{l}\text { Randomized } \\
\text { controlled } \\
\text { trial }\end{array}$ & $\begin{array}{l}\text { EUS celiac plexus } \\
\text { neurolysis vs. nothing }\end{array}$ & 24 & 22 & $\begin{array}{l}\text { Pain, QoL, } \\
\text { opiod } \\
\text { consumption }\end{array}$ & 4 weeks & No \\
\hline [33] & $\begin{array}{l}\text { Randomized } \\
\text { controlled } \\
\text { trial }\end{array}$ & $\begin{array}{c}\text { Intraoperative } \\
\text { splanchnicectomy } \\
\text { using alcohol } \\
\text { neurolysis vs. nothing }\end{array}$ & 23 & 19 & Pain & 4 months & No \\
\hline$[34]$ & $\begin{array}{l}\text { Randomized } \\
\text { controlled } \\
\text { trial }\end{array}$ & $\begin{array}{c}\text { EUS celiac neurolysis } \\
\text { vs. percutaneous celiac } \\
\text { neurolysis }\end{array}$ & 30 & 30 & $\begin{array}{c}\text { Pain and } \\
\text { narcotic } \\
\text { consumption }\end{array}$ & 3 months & No \\
\hline [35] & Retrospective & $\begin{array}{l}\text { Stereotactic body } \\
\text { radiotherapy plus } \\
\text { celiac plexus block vs. } \\
\text { stereotactic body } \\
\text { radiotherapy only }\end{array}$ & 23 & 12 & $\begin{array}{c}\text { Daily } \\
\text { narcotic } \\
\text { consumption }\end{array}$ & 4 months & $\begin{array}{l}\text { Significant } \\
\text { decrease in } \\
\text { celiac plexus } \\
\text { block }\end{array}$ \\
\hline$[36]$ & Retrospective & $\begin{array}{c}\text { EUS celiac neurolysis } \\
\text { vs. percutaneous celiac } \\
\text { neurolysis }\end{array}$ & 24 & 14 & Pain & 4 weeks & No \\
\hline
\end{tabular}

Regarding the type of drugs used for celiac plexus neurolysis, Saleh et al. [37] evaluated the additive value, efficacy and safety of adding dexmedetomidine to bupivacaine and alcohol on pain relief in endoscopic ultrasound-celiac plexus neurolysis (EUS-CPN) for pancreaticcancer-associated pain in 50 patients divided into two groups: Group 1 (25 patients) received bupivacaine $0.5 \%$ alone with alcohol and Group 2 ( 25 patients) received bupivacaine $0.5 \%$ plus dexmedetomidine. The median pain score decreased from $8.32 \pm 0.75$ before the procedure to $3.75 \pm 3.7224$ weeks after the procedure in Group 1 and from $8.08 \pm 0.86$ before to $1.67 \pm 2.3$ 24 weeks after the procedure in Group 2. without significant differences between the two groups in the median pain score during the first 4 weeks.

Alternatively, Filippiadis et al. [38] have reported on a small case series consisting of five patients with pancreatic cancer and pain refractory to conservative medication with the purpose of determining whether percutaneous cryoneurolysis of the splanchnic 
nerves could help in controlling the pain. The mean pain score prior to cryoanalgesia of the splanchnic nerves was 9.4 VAS units. This score was reduced to a mean value of 2.6, 2.6 and 3 VAS units at 1, 3 and 6 months of follow-up, respectively; there was also significantly reduced analgesic usage.

Finally, regarding the symptoms that may affect celiac plexus neurolysis, Facciorusso et al. [39] have shown that in 187 patients successfully treated with EUS CPN, the median duration of pain relief was 8 and 15 weeks in sarcopenic and nonsarcopenic patients, respectively, and this difference was statistically significant, suggesting that sarcopenia represents a predictor of poorer response to celiac plexus neurolysis.

In the case of failure to control pain using celiac plexus neurolysis, Comlek retrospectively investigated the outcomes of splanchnic neurolysis [40]. He found that, in 34 patients in whom there was a failure of pain control with celiac block neurolysis, the majority of the patients responded to splanchnic neurolysis with a VAS score $<4$; the response rates were $76.5 \%$ at two weeks, $84.4 \%$ at 2 months and $71.0 \%$ at 3 months. In addition, $26.5 \%$ at 2 weeks, $30.3 \%$ at two months and $29.0 \%$ at 3 months did not require narcotics. In conclusion, splanchnic neurolysis may be a durable and effective option for pain control in pancreatic cancer patients in whom the neurolysis of the celiac plexus is ineffective.

As reported in a meta-analytic study [41], EUS-CPN associated with opioids in the management of pain may be an option for controlling pain in pancreatic cancer patients. However, there is no evidence of a difference in efficacy among the various techniques used. The data found did not cover a long period of time (more than 12 months); thus, in the near future, the appropriate timing of EUS-CPN (early versus on demand) and a randomized comparison of various techniques should be investigated with the aim of establishing their comparative efficacy.

\section{Concluding Remarks}

Some new markers of neuropathic pain have been suggested from experimental and human studies, but these substances must be evaluated clinically in a consistent number of patients.

Pharmacological studies (Figure 2) have demonstrated that more efficient drugs are required for guiding the neuropathic pain, and, at present, celiac block neurolysis should be reserved for patients with advanced pancreatic cancer and presumed low survival.

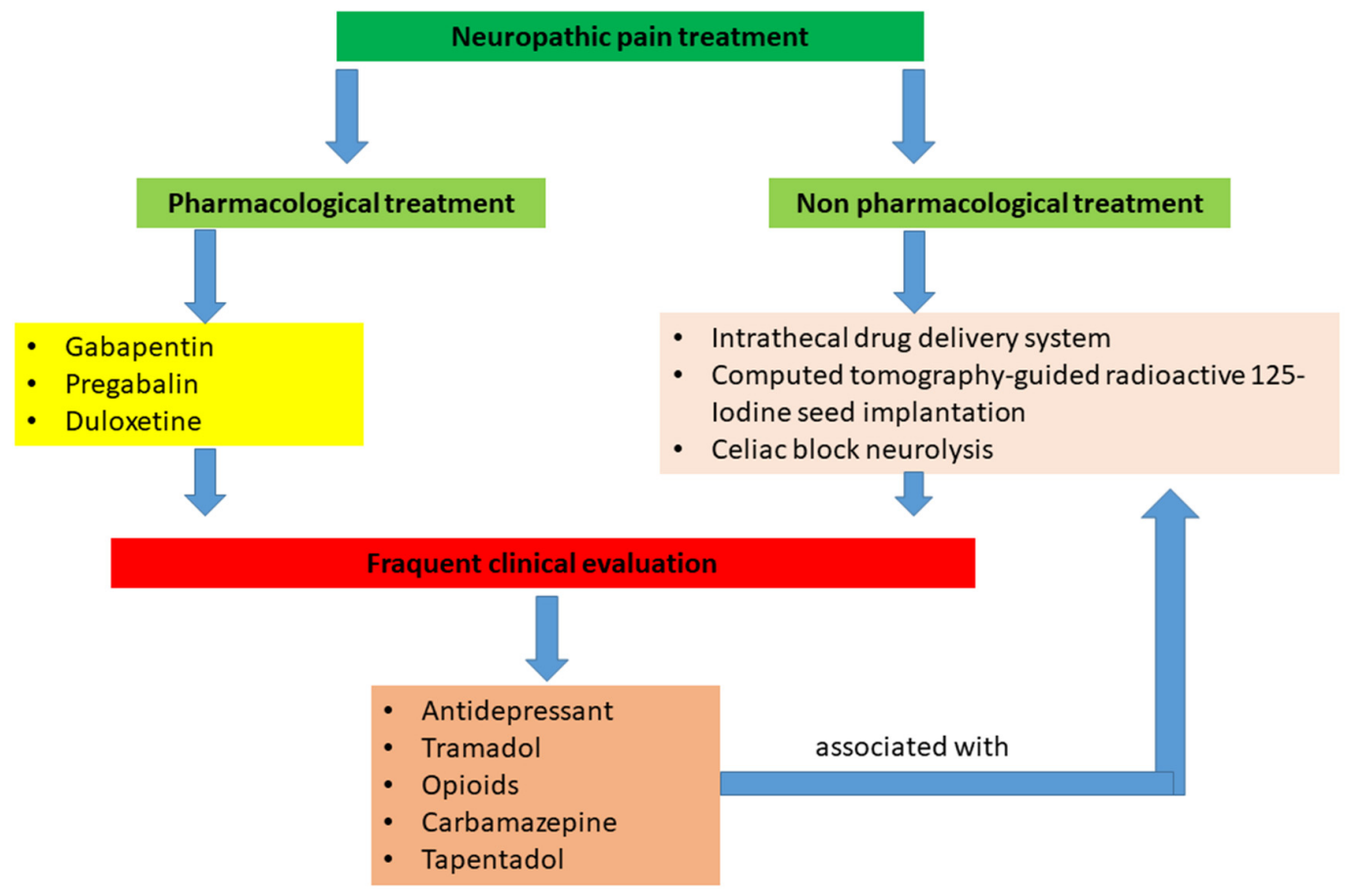

Figure 2. Algorithm of treatment of neuropathic pain. 
Funding: This research received no external funding.

Institutional Review Board Statement: Not applicable.

Informed Consent Statement: Not applicable.

Conflicts of Interest: The author declares no conflict of interest.

\section{References}

1. Yan, B.M.; Myers, R.P. Neurolytic celiac plexus block for pain control in unresectable pancreatic cancer. Am. J. Gastroenterol. 2007, 102, 430-438. [CrossRef]

2. Lebovits, A.H.; Lefkowitz, M. Pain management of pancreatic carcinoma: A review. Pain 1989, 36, 1-11. [CrossRef]

3. Penman, I.D. Coeliac plexus neurolysis. Best Pract. Res. Clin. Gastroenterol. 2009, 23, 761-766. [CrossRef]

4. Caraceni, A.; Portenoy, R.K. Pain management in patients with pancreatic carcinoma. Cancer 1996, 78, 639-653. [CrossRef]

5. Cohen, S.P.; Mao, J. Neuropathic pain: Mechanisms and their clinical implications. BMJ 2014, 348, f7656. [CrossRef] [PubMed]

6. Baron, R. Neuropathic pain: A clinical perspective. Handb. Exp. Pharmacol. 2009, 194, 3-30.

7. Adiwinata, R.; Livina, A.; Waleleng, B.J.; Tendean, N.; Gosal, F.; Rotty, L.; Winarta, J.; Waleleng, A. Palliative management of advanced pancreatic cancer: The role of gastroentero-hepatologist. Acta Med. Indones. 2020, 52, 185-191.

8. Saricaoglu, Ö.C.; Teller, S.; Wang, X.; Wang, S.; Stupakov, P.; Heinrich, T.; Istvanffy, R.; Friess, H.; Ceyhan, G.O.; Demir, I.E. Localisation analysis of nerves in the mouse pancreas reveals the sites of highest nerve density and nociceptive innervation. Neurogastroenterol. Motil. 2020, 32, e13880. [CrossRef] [PubMed]

9. Han, L.; Jiang, J.; Xue, M.; Qin, T.; Xiao, Y.; Wu, E.; Shen, X.; Ma, Q.; Ma, J. Sonic hedgehog signaling pathway promotes pancreatic cancer pain via nerve growth factor. Reg. Anesth. Pain Med. 2020, 45, 137-144. [CrossRef] [PubMed]

10. Zhang, J.; Fu, X.; Liu, D.; Yang, M.; Yang, J.; Huo, Y.; Liu, W.; Hua, R.; Sun, Y.; Wang, J. Molecular markers associated with perineural invasion in pancreatic ductal adenocarcinoma. Oncol. Lett. 2020, 20, 5. [CrossRef] [PubMed]

11. Hirth, M.; Gandla, J.; Höper, C.; Gaida, M.M.; Agarwal, N.; Simonetti, M.; Demir, A.; Xie, Y.; Weiss, C.; Michalski, C.W.; et al. CXCL10 and CCL21 Promote migration of pancreatic cancer cells toward sensory neurons and neural remodeling in tumors in mice, associated with pain in patients. Gastroenterology 2020, 159, 665-681. [CrossRef]

12. Zhu, M.; Wang, L.; Zhu, J.; Xu, H.; Wei, K.; Chen, Q.; Wu, X.; Miao, X.; Lu, Z. MicroRNA-330 directs downregulation of the gaba $_{b} \mathrm{r} 2$ in the pathogenesis of pancreatic cancer pain. J. Mol. Neurosci. 2020, 70, 1541-1551. [CrossRef]

13. Fujisawa, T.; Shimamura, T.; Goto, K.; Nakagawa, R.; Muroyama, R.; Ino, Y.; Horiuchi, H.; Endo, I.; Maeda, S.; Harihara, Y.; et al. A novel role of interlekin 13 receptor alpha2 in perineural invasion and its association with poor prognosis of patients with pancreatic ductal adenocarcinoma. Cancers 2020, 12, 1294. [CrossRef] [PubMed]

14. Mackay, T.M.; Latenstein, A.E.J.; Sprangers, M.A.G.; van der Geest, L.G.; Creemers, G.J.; van Dieren, S.; de Groot, J.B.; Groot Koerkamp, B.; de Hingh, I.H.; Homs, M.Y.V.; et al. Dutch Pancreatic Cancer Group. Relationship between quality of life and survival in patients with pancreatic and periampullary cancer: A multicenter cohort analysis. J. Natl. Compr. Cancer Netw. 2020, 18, 1354-1363. [CrossRef] [PubMed]

15. Park, S.K.; Park, H.A.; Lee, J. Understanding the public's emotions about cancer: Analysis of social media data. Int. J. Environ. Res. Public Health 2020, 17, 7160. [CrossRef] [PubMed]

16. Damm, M.; Weniger, M.; Kölsch, A.K.; Lampert, C.; Ceyhan, G.O.; Beer, S.; Schorn, S.; Moir, J.; Michl, P.; Rosendahl, J. The quality of pain management in pancreatic cancer: A prospective multi-center study. Pancreatology 2020, 20, 1511-1518. [CrossRef]

17. Ramsey, I.; Eckert, M.; Hutchinson, A.D.; Marker, J.; Corsini, N. Core outcome sets in cancer and their approaches to identifying and selecting patient-reported outcome measures: A systematic review. J. Patient Rep. Outcomes 2020, 4, 77. [CrossRef]

18. Guan, M.; Gresham, G.; Shinde, A.; Lapite, I.; Gong, J.; Placencio-Hickok, V.R.; Forrest, C.B.; Hendifar, A.E. Priority rankings of patient-reported outcomes for pancreatic ductal adenocarcinoma: A comparison of patient and physician perspectives. J. Natl. Compr. Cancer Netw. 2020, 18, 1075-1083. [CrossRef]

19. Gustavell, T.; Sundberg, K.; Langius-Eklöf, A. Using an interactive app for symptom reporting and management following pancreatic cancer surgery to facilitate person-centered care: Descriptive study. JMIR Mhealth Uhealth 2020, 8, e17855. [CrossRef] [PubMed]

20. Marinelli, V.; Danzi, O.P.; Mazzi, M.A.; Secchettin, E.; Tuveri, M.; Bonamini, D.; Rimondini, M.; Salvia, R.; Bassi, C.; Del Piccolo, L. Prepare: PreoPerative Anxiety REduction. One-year feasibility rct on a brief psychological intervention for pancreatic cancer patients prior to major surgery. Front. Psychol. 2020, 11, 362. [CrossRef]

21. Maharaj, A.D.; Samoborec, S.; Evans, S.M.; Zalcberg, J.; Neale, R.E.; Goldstein, D.; Merrett, N.; White, K.; Croagh, D.; Pilgrim, C.H.C.; et al. Patient-reported outcome measures (PROMs) in pancreatic cancer: A systematic review. HPB 2020, 22, 187-203. [CrossRef]

22. Kajiwara, I.; Sano, M.; Ichimaru, Y.; Oshima, Y.; Kitajima, O.; Hao, H.; Masamune, A.; Kim, J.; Ishii, Y.; Ijichi, H.; et al. Duloxetine improves cancer-associated pain in a mouse model of pancreatic cancer through stimulation of noradrenaline pathway and its antitumor effects. Pain 2020, 161, 2909-2919. [CrossRef]

23. Kamal, M.; Wang, X.S.; Shi, Q.; Mendoza, T.; Garcia-Gonzalez, A.; Bokhari, R.H.; Cleeland, C.S.; Fogelman, D.R. A randomized, placebo-controlled, double-blind study of minocycline for reducing the symptom burden experienced by patients with advanced pancreatic cancer. J. Pain Symptom Manag. 2020, 59, 1052-1058. [CrossRef] 
24. Fürst, P.; Lundström, S.; Strang, P. Methadone in Swedish specialized palliative care-Is it the magic bullet in complex cancer-related pain? PLOS ONE 2020, 5, e0230845. [CrossRef]

25. Bandieri, E.; Romero, M.; Ripamonti, C.I.; Artioli, F.; Sichetti, D.; Fanizza, C.; Santini, D.; Cavanna, L.; Melotti, B.; Conte, P.F.; et al. Early strong opioid treatment study (ESOT) investigators. Randomized trial of low-dose morphine versus weak opioids in moderate cancer pain. J. Clin. Oncol. 2016, 34, 436-442. [CrossRef] [PubMed]

26. Steele, G.L.; Dudek, A.Z.; Gilmore, G.E.; Richter, S.A.; Olson, D.A.; Eklund, J.P.; Zylla, D.M. Impact of pain, opioids, and the mu-opioid receptor on progression and survival in patients with newly diagnosed stage IV pancreatic cancer. Am. J. Clin. Oncol. 2020, 43, 591-597. [CrossRef]

27. Stearns, L.M.; Abd-Elsayed, A.; Perruchoud, C.; Spencer, R.; Hammond, K.; Stromberg, K.; Weaver, T. Intrathecal drug delivery systems for cancer pain: An analysis of a prospective, multicenter product surveillance registry. Anesth. Analg. 2020, 130, 289-297. [CrossRef]

28. Kone, L.B.; Kunda, N.M.; Tran, T.B.; Maker, A.V. Surgeon-placed continuous wound infusion pain catheters markedly decrease narcotic use and improve outcomes after pancreatic tumor resection. Ann. Surg. Oncol. 2021, 28, 2287-2295. [CrossRef] [PubMed]

29. Buckarma, E.; Thiels, C.A.; Habermann, E.B.; Glasgow, A.; Grotz, T.E.; Cleary, S.P.; Smoot, R.L.; Kendrick, M.L.; Nagorney, D.M.; Truty, M.J. Preoperative opioid use is associated with increased length of stay after pancreaticoduodenectomy. HPB 2020, 22, 1074-1081. [CrossRef] [PubMed]

30. Erosa, S.C.; Haffey, P.R.; Mehta, N.; Gulati, A. Tapentadol, Buprenorphine, and Levorphanol for the Treatment of Neuropathic Pain: A Systematic Review. Curr. Pain Headache Rep. 2021, 25, 18. [CrossRef]

31. Fan, T.; Zhou, J.Y. Computed Tomography-guided 125I Radioactive seed implantation therapy for pancreatic cancer pain. J. Coll. Physicians Surg. Pak. 2020, 30, 364-368.

32. Kanno, Y.; Koshita, S.; Masu, K.; Ogawa, T.; Kusunose, H.; Murabayashi, T.; Sakai, T.; Kozakai, F.; Ito, K. Efficacy of EUS-guided celiac plexus neurolysis compared with medication alone for unresectable pancreatic cancer in the oxycodone/fentanyl era: A prospective randomized control study. Gastrointest. Endosc. 2020, 92, 120-130. [CrossRef]

33. Vahedian, J.; Saraee, A.; Baghai Wadji, M.; Safari, S.; Chavoshi Khamneh, A. Pain relieving effect of intraoperative chemical splanchnicectomy of celiac ganglions in patients with resectable pancreatic or gastric masses: A randomized clinical trial. Pain Res. Manag. 2020, 2020, 2675940. [CrossRef]

34. Yoon, W.J.; Oh, Y.; Yoo, C.; Jang, S.; Cho, S.S.; Suh, J.H.; Choi, S.S.; Park, D.H. EUS-guided versus percutaneous celiac neurolysis for the management of intractable pain due to unresectable pancreatic cancer: A randomized clinical trial. J. Clin. Med. 2020, 9, 1666. [CrossRef] [PubMed]

35. Ji, K.; Shao, Y.J.; Hao, J.L.; Cheng, X.J.; Guan, B.Q.; Liu, W.S.; Chen, L.; Wang, X.; Song, Y.C.; Wang, K.; et al. Celiac plexus block after stereotactic body radiotherapy improves pain relief in locally advanced pancreatic cancer. J. Pain Res. 2020, 13, 919-925. [CrossRef]

36. Dumitrescu, A.; Aggarwal, A.; Chye, R. A retrospective case series of patients who have undergone coeliac plexus blocks for the purpose of alleviating pain due to intra-abdominal malignancy. Cancer Rep. 2020, 3, e1265.

37. Saleh, A.A.G.; Sultan, A.; Hammouda, M.A.; Shawki, A.; El Ghaffar, M.A. Value of adding dexmedetomidine in endoscopic ultrasound-guided celiac plexus neurolysis for treatment of pancreatic cancer-associated pain. J. Gastrointest. Cancer 2021, 52, 682-689. [CrossRef] [PubMed]

38. Filippiadis, D.; Ptohis, N.; Efthymiou, E.; Kelekis, A. A technical report on the performance of percutaneous cryoneurolysis of splanchnic nerves for the treatment of refractory abdominal pain in patients with pancreatic cancer: Initial experience. Cardiovasc. Interv. Radiol. 2021, 44, 789-794. [CrossRef] [PubMed]

39. Facciorusso, A.; Antonino, M.; Muscatiello, N. Sarcopenia represents a negative prognostic factor in pancreatic cancer patients undergoing EUS celiac plexus neurolysis. Endosc. Ultrasound 2020, 9, 238-244. [CrossRef] [PubMed]

40. Comlek, S. Pain control with splanchnic neurolysis in pancreatic cancer patients unresponsive to celiac plexus neurolysis. J. Pain Res. 2020, 13, 2023-2031. [CrossRef]

41. Koulouris, A.I.; Alexandre, L.; Hart, A.R.; Clark, A. Endoscopic ultrasound-guided celiac plexus neurolysis (EUS-CPN) technique and analgesic efficacy in patients with pancreatic cancer: A systematic review and meta-analysis. Pancreatology 2021, 21, 434-442. [CrossRef] [PubMed] 